\title{
Preparation of Activated Carbon from Banana Peel Waste as Adsorbent for Motor Vehicle Exhaust Emissions
}

\author{
Yuliusman ${ }^{1, *}$, Jervis Sinto ${ }^{1}$, Yugo Widhi Nugroho ${ }^{1}$, and Hizba Ilmi Naf'an ${ }^{1}$ \\ ${ }^{1}$ Universitas Indonesia, Department of Chemical Engineering, 16424 Depok, Indonesia
}

\begin{abstract}
Air pollution caused by motor vehicle exhaust emissions in the form of harmful gases becomes a problem for the health of living things in the surrounding environment. The alternative way to reduce those emissions is by utilizing agricultural waste as activated carbon (AC). AC can adsorbs those emissions due to its porous and high surface area. AC was made of banana peel waste that contains of lignocellulose and has considerable amount because of banana processing industrialization. $\mathrm{AC}$ was made through dehydration, carbonization at $350^{\circ} \mathrm{C}$ furnace without or with $\mathrm{N}_{2}$ gases of $0.15 \mathrm{NL} /$ minute for 1 hour, then chemical activation using various concentrations of $\mathrm{H}_{2} \mathrm{SO}_{4}$ solution at $85^{\circ} \mathrm{C}$ for 1 hour. Characterization of activated carbon was done by iodine number test. The result shows that carbon chemical activation by $6 \mathrm{~N}^{\circ} \mathrm{H}_{2} \mathrm{SO}_{4}$ gave better result of iodine number than the lower concentration, obtaining $428 \mathrm{mg} / \mathrm{g}$ and overall yield of $41.68 \%$. The result was even better on physical-and-chemical activation with same concentration of $\mathrm{H}_{2} \mathrm{SO}_{4}$, obtaining $617 \mathrm{mg} / \mathrm{g}$ with surface area of $614 \mathrm{~m}^{2} / \mathrm{g}$ and overall yield of $56.40 \%$.
\end{abstract}

\section{Introduction}

Air pollution is one of serious problems that can be seen in everyday life. It refers to contamination of atmosphere by harmful gases that are dangerous for human health or surrounding environment. There are many cause of air pollution in this world, but one of the main cause that widely recognised to be a large source of air pollution globally comes from transportation sector [1]. In transportation, almost all motor vehicles emit exhaust emission gases from the combustion process of liquid fossil fuel.

A complete combustion of the fossil fuel produces carbon dioxide $\left(\mathrm{CO}_{2}\right)$ and water vapour $\left(\mathrm{H}_{2} \mathrm{O}\right)$ as motor vehicle exhaust emissions. However, if combustion is incomplete, a small fraction of the fuel is oxidized only as carbon monoxide (CO) and some volatile hydrocarbons in the form of vapour also emitted. In addition, fuels that are composed of hydrocarbons mixture may also contain some impurities and sulphur is one of those impurities. When sulphur is oxidized on combustion, it mostly turns into sulphur dioxide $\left(\mathrm{SO}_{2}\right)$ and sometimes to sulphate that can assist nucleation particles in exhaust. Another exhaust emission gas is nitric oxide (NO) that comes from oxidation of atmospheric nitrogen at high combustion temperatures together with nitrogen dioxide $\left(\mathrm{NO}_{2}\right)$ in small quantities.

One of ways to remove pollutants in exhaust gases that known and often used is by using adsorbents. Many forms of adsorbents used in industry, such as silica gel, alumina, zeolite, bauxite, and activated carbon [2]. Activated carbon is the most frequently used adsorbent in industry and has displaced many other materials in solvent recovery systems due to the highly adsorption capability [3]. As adsorbent, activated carbon can adsorb a large amount of pollutants due to its large pore volume [4].

Activated carbon can be made using organic matters that contain lignocellulose in the form of cellulose, hemicellulose, and lignin as raw material which can be found in agricultural wastes [5]. Agricultural wastes such as coconut shell, pistachio shells, bamboo, and waste coffee beans are the examples. One of agricultural wastes that can be found commonly in everyday life is banana peel. In 2014 among the tropical fruits, banana was the most commonly eaten fruit in the world [6]. Banana peels become a solid waste of banana processing during production of foods such as banana chips, fried bananas, and unripe banana biomass in human society [7]. Banana cultivation and industrialization generates a considerable amount of waste that is rich in cellulose and starch, which makes this waste is potential as a raw material to make activated carbon [8-9]. Therefore, this paper aims to prepare activated carbon made from banana peel waste as an adsorbent that has potential to be used to adsorbs exhaust emission gases emitted from motor vehicle.

There are several processes to make agricultural waste turns into activated carbon, such as dehydration, carbonization, and activation. The activation process can be a chemical activation or physical activation and is used to get larger surface area of activated carbon. Various chemical activating agent can be used in chemical activation process, such as $\mathrm{ZnCl}_{2}, \mathrm{KOH}$,

Corresponding author: usman@che.ui.ac.id 
$\mathrm{H}_{2} \mathrm{SO}_{4}, \mathrm{H}_{3} \mathrm{PO}_{4}, \mathrm{HNO}_{3}$, etc. [10]. Recently, various types of raw material, chemical activating agent, and physical activation method in the making process of activated carbon are studied [11-13].

One of recent studies had made activated carbons from banana peel waste for adsorbed natural gas application with the use of $\mathrm{ZnCl}_{2}$ as the activating agent [14]. The production of activated carbons from banana peel waste in this study are based on that study. However, there are differences in the application and the chemical activating agent. Activated carbons in this study are made for adsorbed motor vehicle exhaust emission application.

The chemical activating agent selected in this study is sulphuric acid $\left(\mathrm{H}_{2} \mathrm{SO}_{4}\right)$. It is known that the use of $\mathrm{H}_{2} \mathrm{SO}_{4}$ as an activating agent is more favoured than $\mathrm{ZnCl}_{2}$ due to problems of environmental contamination with zinc $(\mathrm{Zn})$ compounds [15]. The use of $\mathrm{H}_{2} \mathrm{SO}_{4}$ as chemical activating agent can develop porous structure by degrading the amorphous domains of cellulosic materials and carbon framework aromatization [16].

In this study, the concentration of $\mathrm{H}_{2} \mathrm{SO}_{4}$ used in chemical activation process was varied to get how much effect of $\mathrm{H}_{2} \mathrm{SO}_{4}$ concentration on the surface area of activated carbon produced. It is also known that physical and chemical activation both can be used in the making process of activated carbon instead of using chemical or physical activation only [17]. Therefore, in this study there was also addition of physical activation by using nitrogen $\left(\mathrm{N}_{2}\right)$ gas stream at high temperature before chemical activation process. Either chemical activated only and physical-chemical activated carbon are studied to get how much differences of activated carbon surface area made from banana peel waste by using those two type activation methods.

\section{Material and methods}

\subsection{Material}

There were several materials used in this study. The raw material used to make activated carbon was peel of ripe Kepok banana. Chemical activating agent that used in chemical activation process was $\mathrm{H}_{2} \mathrm{SO}_{4}$ solution with various concentrations. The concentrations of $\mathrm{H}_{2} \mathrm{SO}_{4}$ solution used were $1 \mathrm{~N}, 2 \mathrm{~N}, 4 \mathrm{~N}$, and $6 \mathrm{~N}$. Nitrogen gas was used at one of the treatments variation of the sample at carbonization process. Distilled water was used to rinse activated carbon until the $\mathrm{pH}$ is in neutral range.

\subsection{Dehydration of banana peels}

Before dehydration process, banana peels waste were cleaned and separated from any other trash that might mixed together when banana peels waste were collected. The cleaned banana peels waste then were drying in an oven with $105^{\circ} \mathrm{C}$ temperature until dried. The purpose of this step is to reduce amount of water, which is contained in banana peel. After the banana peels were dried, banana peels were mashed with a mortar and pestle to reduce size of dried banana peels.

\subsection{Carbonization of dried banana peels}

The amount of size-reduced dried banana peels were divided into two parts. The first part was carbonized at furnace without stream of $\mathrm{N}_{2}$ gases and the other part is carbonized at reactor with stream of $\mathrm{N}_{2}$ gases. The flow of $\mathrm{N}_{2}$ gases was set at $0.15 \mathrm{NL} / \mathrm{min}$. Carbonization process for both parts was carried out at $350^{\circ} \mathrm{C}$ for 1 hour. The carbonization process that took place in the absence of nitrogen gas stream produces carbon that is not yet activated. While the one of carbonization process that was carried out in high temperature and with stream of $\mathrm{N}_{2}$ gases produces carbon that is physical activated. For both types carbon produced after carbonization, the carbons were mashed again with a mortar and pestle then were sieved with 30-mesh sieve to uniform size of carbons produced.

\subsection{Chemical activation of carbon}

Both types of carbon were broken down into four parts. Each part was immersed in a $\mathrm{H}_{2} \mathrm{SO}_{4}$ solution at different concentration separately. The ratio of the volume of $\mathrm{H}_{2} \mathrm{SO}_{4}$ solution to the carbon mass used at all concentration tested was $3 \mathrm{~mL}$ of $\mathrm{H}_{2} \mathrm{SO}_{4}$ solution for each $1 \mathrm{~g}$ carbon used. The mixture of carbon and $\mathrm{H}_{2} \mathrm{SO}_{4}$ solution then were heated at $85^{\circ} \mathrm{C}$ for 1 hour. After chemical activation was completed, the carbon is chemical activated.

\section{$2.5 \mathrm{pH}$ neutralization of activated carbon}

After chemical activation, there is a change in $\mathrm{pH}$ of activated carbon caused by the use of chemical activating agent. In order to neutralize the $\mathrm{pH}$ of activated carbon, the activated carbon was rinsed by distilled water. The activated carbon was rinsed repeatedly until the $\mathrm{pH}$ is close to neutral. For each rinsing, the distilled water that added to the activated carbon had been stirred using a stirrer for 10 minutes. After stirring, the mixture was filtered using filter paper and a vacuum filter. When $\mathrm{pH}$ of activated carbon had been close to neutral, the rinsing was stopped and the wet activated carbon was dried in an oven at $110^{\circ} \mathrm{C}$ for 1 hour. After drying, the activated carbon was stored for the iodine test.

\section{6 lodine number test of activated carbon}

Iodine number test is used to measuring adsorption capability of activated carbon in an iodine solution. Iodine number measured how much iodine $(\mathrm{mg})$ that can been adsorbed by each gram of activated carbon used. The mixture of carbon and iodine solution was filtrated using filter paper and the filtrate was titrated by sodium thiosulfate $\left(\mathrm{Na}_{2} \mathrm{~S}_{2} \mathrm{O}_{3}\right)$. The filtrate refers to iodine solution that is not adsorbed by activated carbon. During titration, a little amount of starch solution was added to clarify the endpoint of titration. The titration was ended when the mixture that was originally pale yellow- 
coloured changed into transparent. The equation for calculating the iodine number is as follows.

$$
W=\frac{\left(V_{B}-V_{T}\right) \times M_{T} \times N M_{I} \times \frac{V_{f}}{V_{Z}}}{m_{M E}}
$$

where:

IN Iodine number $(\mathrm{mg} / \mathrm{g})$

$\mathrm{V}_{\mathrm{B}} \quad$ Volume of iodine to be titrated (mL)

$\mathrm{V}_{\mathrm{T}} \quad$ Volume of sodium thiosulphate used (mL)

$\mathrm{N}_{\mathrm{T}} \quad$ Normality of sodium thiosulfate $(\mathrm{N})$

$\mathrm{M}_{\mathrm{I}} \quad$ Iodine molar mass $(\mathrm{g} / \mathrm{mole})$

$\mathrm{V}_{\mathrm{I}} \quad$ Initial volume of iodine $(\mathrm{mL})$

$\mathrm{m}_{\mathrm{AC}} \quad$ Mass of activated carbon $(\mathrm{g})$

The iodine number obtained was then used to projecting the surface area of the activated carbon using the equation as follows [18].

$$
S_{I}=\frac{I N \times 10^{-3}}{M_{I}} \times N \times \omega_{I}
$$

where:

$\mathrm{S}_{\mathrm{I}} \quad$ Surface area based on iodine number $\left(\mathrm{m}^{2} / \mathrm{g}\right)$

IN Iodine number $(\mathrm{mg} / \mathrm{g})$

$10^{-3} \quad$ Convertion factor $(\mathrm{g} / \mathrm{mg})$

$\mathrm{M}_{\mathrm{I}} \quad$ Iodine molecular mass $=126.92 \mathrm{~g} / \mathrm{mole}$

$\mathrm{N} \quad$ Avogadro constant $=6.023 \times 10^{23} \mathrm{~mol}^{-1}$

$\omega_{\text {I }} \quad$ Hypothetical surface area per iodine atom at dense packing $\left(\mathrm{m}^{2}\right)$

\section{Results and discussion}

\subsection{Dehydration of banana peels}

Dehydration process of banana peels lasts for 24 hours in the oven. There are changes in banana peels condition before and after dehydration. Before had been dehydrated, banana peels were yellow-coloured, mushy, and not rather light. However, after had been dehydrated, banana peels were black-coloured, hard, and lighter. This was happened because there is reduction in water content of banana peels. The mushy condition of banana peels means there is still a high water content in banana peels, but banana peels become hard and lighter as a result of water content removal from banana peels. High temperature of oven makes waters contained in banana peels are evaporated into the air and leave from banana peels.

\subsection{Carbonization of dried banana peels}

The carbonization results for both types of carbonization treatments can be seen in Table 1 .

\begin{tabular}{|c|c|c|c|}
\hline $\begin{array}{c}\text { Carbonization } \\
\text { Type }\end{array}$ & $\begin{array}{c}\text { Initial } \\
\text { Mass (g) }\end{array}$ & $\begin{array}{c}\text { Final } \\
\text { Mass }(g)\end{array}$ & $\begin{array}{c}\text { Yield } \\
(\%)\end{array}$ \\
\hline \multirow{3}{*}{$\begin{array}{c}\text { Without } \mathrm{N}_{2} \text { gas } \\
\text { stream }\end{array}$} & 9.00 & 3.99 & 44.33 \\
\hline & 12.00 & 5.68 & 47.33 \\
\hline & 15.00 & 7.39 & 49.27 \\
\hline $\begin{array}{l}\text { With } \mathrm{N}_{2} \text { gas } \\
\text { stream at } 0.15\end{array}$ & 30.00 & 19.76 & 65.87 \\
\hline NL/minute & 40.00 & 26.58 & 66.45 \\
\hline
\end{tabular}

Table 1. Carbon yields as carbonization result

As can be seen in the Table 1, the carbon final mass produced by the carbonization process without nitrogen gas stream was not as large as the carbon final mass produced by the carbonization process accompanied by the nitrogen gas stream. The average carbon yield that produced from carbonization without nitrogen gas stream was $47.39 \%$. Meanwhile, the average carbon yield that produced from carbonization in the presence of nitrogen gas stream was $66.20 \%$. The presence of a nitrogen gas stream prevents the presence of oxygen gas around the carbon that has the potential to decompose carbon excessively and damage the carbon structure. The more damaged the carbon structure cause the carbon structure to become more fragile and lighter than carbon that is still solid structured or less damaged. In the absence of an inert gas stream like nitrogen around the carbon, the oxygen gas in the air is easier to fill in the free space around the carbon and to decompose carbon in excess.

\subsection{Chemical activation of carbon}

The chemical activation results for both not yet activated and physical activated carbon are shown in Table 2.

Table 2. Mass increase of chemical activated carbon

\begin{tabular}{ccccc}
\hline $\begin{array}{c}\text { Carbon } \\
\begin{array}{c}\text { Feed } \\
\text { Type }\end{array}\end{array}$ & $\begin{array}{c}\mathrm{H}_{2} \mathrm{SO}_{4} \\
(\mathrm{~N})\end{array}$ & $\begin{array}{c}\text { Initial } \\
\text { Mass } \\
(\mathrm{g})\end{array}$ & $\begin{array}{c}\text { Final } \\
\text { Mass } \\
(\mathrm{g})\end{array}$ & $\begin{array}{c}\text { Mass } \\
\text { Increase } \\
(\%)\end{array}$ \\
\hline $\begin{array}{c}\text { Not } \\
\text { physical } \\
\text { activated }\end{array}$ & 1 & 2.00 & 2.10 & 5.00 \\
& 2 & 2.00 & 2.30 & 15.00 \\
& 6 & 2.00 & 2.83 & 41.50 \\
& 1 & 2.00 & 3.64 & 82.00 \\
& 2 & 2.00 & 52.40 & 162.00 \\
\hline $\begin{array}{c}\text { Physical } \\
\text { activated }\end{array}$ & 4 & 2.00 & 2.32 & 16.00 \\
& 6 & 2.00 & 2.84 & 42.00 \\
& & 20.00 & 60.20 & 201.00
\end{tabular}


Based on Table 2, the chemical activation process was made carbon mass increased. In a carbon immersion with a chemical activating agent, the chemical activating agent came in between the hexagonal layers and opened the closed surface subsequently [19]. Therefore, when mixing of carbon and $\mathrm{H}_{2} \mathrm{SO}_{4}$ solution is being done, ions from $\mathrm{H}_{2} \mathrm{SO}_{4}$ come between layers of carbon so the $\mathrm{H}_{2} \mathrm{SO}_{4}$ solution mass causes the total mass of carbon increased. The increase of $\mathrm{H}_{2} \mathrm{SO}_{4}$ concentration causes more ions from $\mathrm{H}_{2} \mathrm{SO}_{4}$ come in carbon so the mass increase is larger than the smaller one.

The increase of mass on physical activated feed carbon was larger than the not physical activated one. This was because the physical activated feed carbon tends to has stronger and more solid structure than the not physical activated one, so there is also more of carbon layers that ions from $\mathrm{H}_{2} \mathrm{SO}_{4}$ can come in between. The initial carbon mass difference that was used for chemical activation also affects the final mass of activated carbon, because by the same temperature and heating procedure, the heat load that must be transferred to carbon is different. The less amount of carbon used, the better heat transferred to the carbon so that more volatile substances in the mixture of carbon and $\mathrm{H}_{2} \mathrm{SO}_{4}$ solution released into the air.

\section{$3.4 \mathrm{pH}$ neutralization of activated carbon}

\subsubsection{Rinse of activated carbon}

The rinse of activated carbon aims to neutralize $\mathrm{pH}$ of activated carbon because of adding of chemical solution during activated carbon production. The rinse of activated carbon also used for removing other contaminants that still remain on the previous steps. In this study, $\mathrm{H}_{2} \mathrm{SO}_{4}$ solution was used as the chemical activating agent so it made the initial $\mathrm{pH}$ of the activated carbon produced was acidic. The rinse of activated carbon was done by using distilled water repeatedly until $\mathrm{pH}$ of activated carbon close to be 7 or neutral. However, the $\mathrm{pH}$ of distilled water was only six, so the $\mathrm{pH}$ of activated carbon after repeatedly rinse can only make up to six. To increase $\mathrm{pH}$ of activated carbon, additional base chemical solution is required. However, it is not be done in this study to prevents any other effect that can be occurred to activated carbon characteristic.

The first of rinsing process resulted a filtrate that was dirty and yellow in colour. It showed that in first rinse of activated carbon, the $\mathrm{pH}$ of filtered activated carbon was still low or acidic. When the rinse was being done repeatedly, the filtrate slowly became cleaner and more clear or transparent. The colour change shows that $\mathrm{pH}$ of the rinsed activated carbon is being closer to be neutral. The ions from $\mathrm{H}_{2} \mathrm{SO}_{4}$ that make activated carbon acidic are carried together with distilled water during the filtering process. However, during that process some part of ions from $\mathrm{H}_{2} \mathrm{SO}_{4}$ still remain in activated carbon and not carried together by distilled water. It makes the rinsing process to neutralize $\mathrm{pH}$ of activated carbon can not be done only once, but must done repeatedly.
The required distilled water volume to neutralize the activated carbon was vary on the use of different $\mathrm{H}_{2} \mathrm{SO}_{4}$ concentration at chemical activation process. The effect of $\mathrm{H}_{2} \mathrm{SO}_{4}$ concentration used at chemical activation on required distilled water volume for chemical activated carbon is shown in Figure 1. The chemical activated carbon used was the small amount type of carbon (the carbon that around $2 \mathrm{~g}$ before chemical activation)

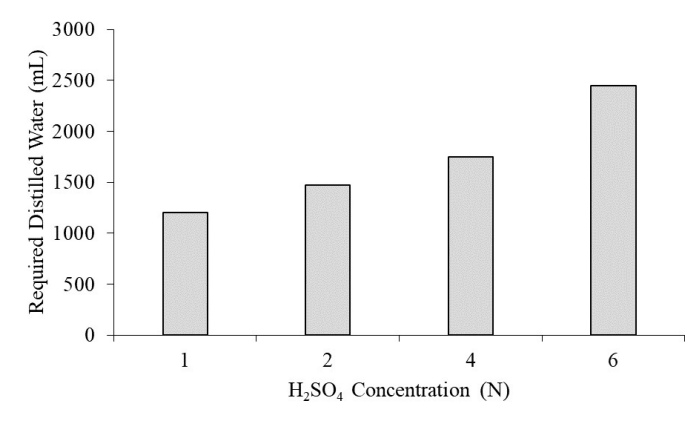

Fig. 1. Effect of $\mathrm{H}_{2} \mathrm{SO}_{4}$ concentration used on required distilled water volume for activated carbon rinsing (small amount)

In the Figure 1, the type of activated carbon that used higher concentration of $\mathrm{H}_{2} \mathrm{SO}_{4}$ solution required more distilled water to neutralize the activated carbon. Higher concentration of $\mathrm{H}_{2} \mathrm{SO}_{4}$ solution used makes more of remaining ions from $\mathrm{H}_{2} \mathrm{SO}_{4}$ in between carbon layers. Therefore, the carbon that activated with higher concentration of $\mathrm{H}_{2} \mathrm{SO}_{4}$ solution has lower initial $\mathrm{pH}$ than the lower one. To increase $\mathrm{pH}$ of activated carbon with lower initial $\mathrm{pH}$ required more of distilled water.

The comparison of required distilled water volume for chemical activated and physical-chemical activated carbon in big amount (the carbon that around $20 \mathrm{~g}$ before chemical activation) is shown in Table 3 . Distilled water around $800 \mathrm{~mL}$ was used each rinse of carbon in big amount.

Table 3. Required distilled water volume in activated carbon rinsing (big amount)

\begin{tabular}{cccc}
\hline Carbon Type & $\begin{array}{c}\text { Initial } \\
\text { Mass } \\
(\mathrm{g})\end{array}$ & $\begin{array}{c}\text { Required } \\
\text { Distilled } \\
\text { Water } \\
(\mathrm{mL})\end{array}$ & $\begin{array}{c}\text { Number } \\
\text { of } \\
\text { Washes } \\
\text { (times) }\end{array}$ \\
\hline $\begin{array}{c}\text { Chemical activated } \\
\mathrm{H}_{2} \mathrm{SO}_{4} 6 \mathrm{~N}\end{array}$ & 52.40 & 5,650 & 7 \\
\hline $\begin{array}{c}\text { Physical-chemical } \\
\text { activated } \mathrm{H}_{2} \mathrm{SO}_{4} 6 \mathrm{~N}\end{array}$ & 60.20 & 8,800 & 11 \\
\hline
\end{tabular}

From Table 3, distilled water to neutralize physicalchemical activated carbon was more required than the chemical activated one. The physical-chemical activated carbon has stronger and more solid structure than chemical activated one that makes more ions from $\mathrm{H}_{2} \mathrm{SO}_{4}$ come in between carbon layers. Therefore, the initial $\mathrm{pH}$ of physical-chemical activated carbon was lower than chemical activated one so more distilled water is required to increase $\mathrm{pH}$ of the activated carbon during rinsing. 


\subsubsection{Drying of wet activated carbon}

After the rinsing process, the wet activated carbon was filtered with filter paper then dried in oven. During the drying process, water content in activated carbon was decreasing until the activated carbon became dried. Table 4 shows result of dried activated carbons yield.

Table 4. Yield of activated carbon after rinsing and drying process

\begin{tabular}{ccccc}
\hline $\begin{array}{c}\text { Carbon } \\
\text { Type }\end{array}$ & $\begin{array}{c}\mathrm{H}_{2} \mathrm{SO}_{4} \\
\text { Concentration } \\
(\mathrm{N})\end{array}$ & $\begin{array}{c}\text { Mass } \\
\text { Before } \\
\text { Rinsing } \\
(\mathrm{g})\end{array}$ & $\begin{array}{c}\text { Mass } \\
\text { After } \\
\text { Drying } \\
(\mathrm{g})\end{array}$ & $\begin{array}{c}\text { Yield } \\
(\%)\end{array}$ \\
\hline & 1 & 2.10 & 1.29 & 61.43 \\
$\begin{array}{c}\text { Chemical } \\
\text { activated }\end{array}$ & 4 & 2.30 & 1.35 & 58.70 \\
& 6 & 2.83 & 1.35 & 47.70 \\
& 1 & 3.64 & 1.45 & 39.84 \\
& 2 & 52.40 & 17.59 & 33.56 \\
\hline $\begin{array}{l}\text { Physical- } \\
\text { chemical }\end{array}$ & 4 & 2.13 & 1.55 & 72.77 \\
activated & & 2.84 & 1.32 & 56.03 \\
& 6 & 3.94 & 1.41 & 35.79 \\
& & 60.20 & 17.04 & 28.30 \\
\hline
\end{tabular}

From Table 4, activated carbons that activated with higher $\mathrm{H}_{2} \mathrm{SO}_{4}$ concentration had lower yields than the lower one. It was because activated carbons that more acidic are also lost more ions from $\mathrm{H}_{2} \mathrm{SO}_{4}$ during the rinsing process that make the yields decreased more. It is also known from Table 4 that the carbons final mass not became the initial carbons mass before chemical activation (neither $2 \mathrm{~g}$ or $20 \mathrm{~g}$ ). It was because there are some contaminants in activated carbon that removed by $\mathrm{H}_{2} \mathrm{SO}_{4}$ solution and there are some parts of activated carbon that cannot be retrieved due to sticking on the filter paper.

\section{5 lodine number test of activated carbon}

\subsection{1 lodine number results}

Figure 2 shows the effect of various $\mathrm{H}_{2} \mathrm{SO}_{4}$ concentrations used at chemical activation to iodine number of activated carbons produced.

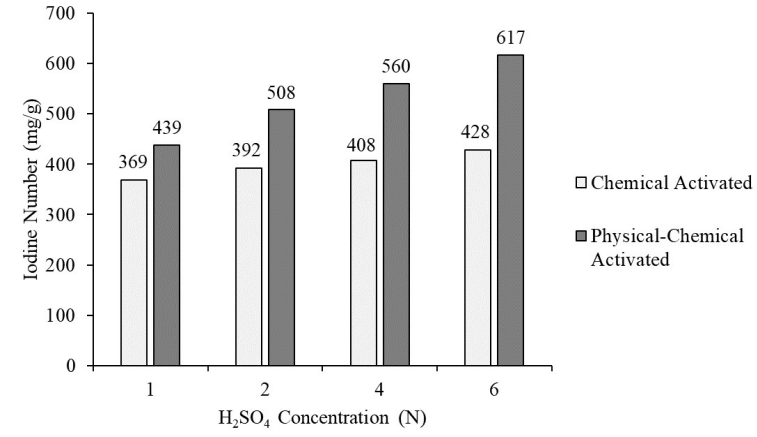

Fig. 2. Effect of $\mathrm{H}_{2} \mathrm{SO}_{4}$ concentration on iodine number of activated carbon

Iodine number was calculated by using Equation 1 . Iodine number test on not yet activated carbon made from banana peel in this study was $362 \mathrm{mg} / \mathrm{g}$. After going through the activation process, the iodine number was increased. The increase of iodine number varies as a result of various $\mathrm{H}_{2} \mathrm{SO}_{4}$ concentrations used as chemical activating agent. The greatest iodine number in chemical activated only carbon found with use of $\mathrm{H}_{2} \mathrm{SO}_{4} 6 \mathrm{~N}$, which was $428 \mathrm{mg} / \mathrm{g}$. Meanwhile, the greatest iodine number in physical-chemical activated carbon found with use of $\mathrm{H}_{2} \mathrm{SO}_{4} 6 \mathrm{~N}$, which was $617 \mathrm{mg} / \mathrm{g}$. According to Figure 2, higher $\mathrm{H}_{2} \mathrm{SO}_{4}$ concentration used at chemical activation results higher iodine adsorption capacity. Adsorption capability of activated carbon is stronger correspondingly with the increase of chemical activating agent concentration [20].

$\mathrm{H}_{2} \mathrm{SO}_{4}$ solution acts as dehydration agent, where $\mathrm{H}_{2} \mathrm{SO}_{4}$ solution releases water molecules when elimination of oxygen and hydrogen atoms occurs from carbon materials. This is caused further pores formation of the carbon. Higher $\mathrm{H}_{2} \mathrm{SO}_{4}$ concentration used means more ions from $\mathrm{H}_{2} \mathrm{SO}_{4}$ bind impurities that cover carbon pores and make carbon pores open.

Meanwhile, the availability of physical activation before chemical activation makes the iodine number was greater than chemical activated only carbon. This was because the nitrogen gas used in physical activation help to opens the pores of carbon that are still closed. Nitrogen gas stream acts to develop porous structures in carbon by removing tars and volatile substances on carbon during carbonization process. In addition, physical activation by inert gas stream such as nitrogen also helps to prevent occurrence of excessive oxidation due to presence of oxygen gas that damages carbon pore structures.

\subsubsection{Surface area projection}

The obtained iodine number results then used to project the surface area of activated carbons by using Equation 2. Figure 3 shows the effect of $\mathrm{H}_{2} \mathrm{SO}_{4}$ concentrations used at chemical activation on surface area of activated carbon. 


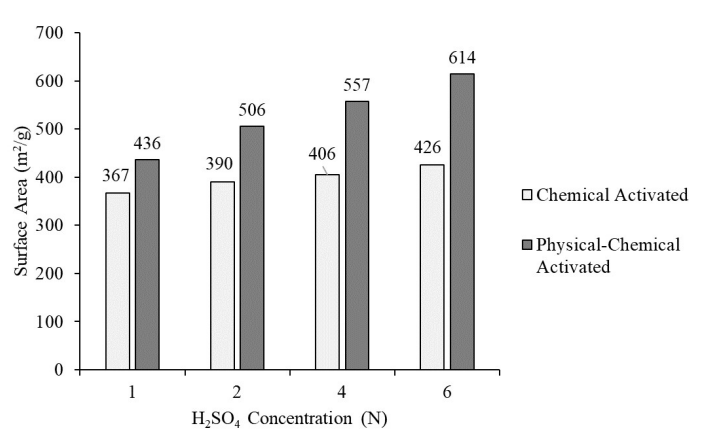

Fig. 3. Effect of $\mathrm{H}_{2} \mathrm{SO}_{4}$ concentration on surface area of activated carbon

The surface area of not yet activated carbon made from banana peel in this study was obtained at $360 \mathrm{~m}^{2} / \mathrm{g}$. As can be seen in Figure 3, the chemical activation process with $\mathrm{H}_{2} \mathrm{SO}_{4}$ solution increases the surface area of the activated carbons. The increase in surface area was also proportional to the additional presence of physical activation and increased concentration of $\mathrm{H}_{2} \mathrm{SO}_{4}$ solution used as well as in the case of increased iodine numbers. This means the amount of iodine that can be adsorbed activated carbon on iodine number can represent how much activated carbon adsorption capability in the form of surface area data.

Based on Figure 3, it was also known the type of activated carbon that had the best surface area based on activation method and $\mathrm{H}_{2} \mathrm{SO}_{4}$ concentration used. The best type of activated carbon from the chemical activation only method was with the use of $\mathrm{H}_{2} \mathrm{SO}_{4} 6 \mathrm{~N}$, which was $426 \mathrm{~m}^{2} / \mathrm{g}$. Meanwhile, the best type of activated carbon from the combined physical-chemical activation method was with the use of $\mathrm{H}_{2} \mathrm{SO}_{4} 6 \mathrm{~N}$, which was $614 \mathrm{~m}^{2} / \mathrm{g}$.

Recently, there is a study of pollutants removal in diesel engines by using activated carbon [21]. In that study, some of activated carbons studied had surface area about $450-500 \mathrm{~m}^{2} / \mathrm{g}$ and can efficiently remove about $45-48 \%$ of pollutants in exhaust gases from diesel engines. The activated carbons produced in this study had higher and lower surface area than activated carbons tested from that study. Therefore, the activated carbons made in this study could also reduce pollutant gases content around that much and are well prepared to be used as adsorbent for motor vehicle exhaust emission.

\section{Conclusion}

It can be concluded from this study that activated carbons made from banana peel are well prepared to be used as adsorbent for motor vehicle exhaust emission. The greatest activated carbon surface area based on chemical concentration used in chemical only activation method was obtained on the use of $\mathrm{H}_{2} \mathrm{SO}_{4} 6 \mathrm{~N}$, which was $426 \mathrm{~m}^{2} / \mathrm{g}$. Therefore, the increase of $\mathrm{H}_{2} \mathrm{SO}_{4}$ concentration used at chemical activation process is increasing the surface area of activated carbon. However, the activated carbon surface area was greater in physical-chemical activation method than the chemical only activation on the same concentration, which was $614 \mathrm{~m}^{2} / \mathrm{g}$. It makes that activated carbon had the greatest surface area in this study. It shows physicalchemical activation method was better than chemical only activation method. The additional physical activation method in the making process of activated carbon helps to remove impurities that cover carbon pores and increase the activated carbon surface area.

This research was funded by "Hibah PITTA Mahasiswa Universitas Indonesia 2018" from Directorate of Research and Community Service Universitas Indonesia (DRPM-UI). The author declares no conflicts of financial interest.

\section{References}

[1] Colvile, R.N., E.J. Hutchinson, J.S. Mindell., R.A. Warren. Atmos. Environ. 35, 9 (2000)

[2] Blocki, S.W. Environ. Prog. 12, 1 (1993)

[3] Cooper, D.C., F.C. Alley. Air Pollution Control: a Design Approach. (Waveland Press, Illinois, 1994)

[4] Reinmerink, W.M.T.M., D. v.d. Kleut. Stud. Surf. Sci. Catal. 120, 1 (1998)

[5] Yuliusman, Nasruddin, M.K. Afdhol, R.A. Amiliana, A. Hanafi, B. Rachmanda. IOP Conf. Ser.: Mater. Sci. Eng. 180, 1 (2017)

[6] Hasanah, N.N. Going Banana for A Healthier Lifestyle. (Directorate General of National Export Development, Jakarta, 2016)

[7] Tibolla, H., F.M. Pelissari, J.T. Martins, A.A. Vicente, F.C. Menegalli. Food Hydrocolloids 75, 192-201 (2018)

[8] Elanthikkal, S., U. Gopalakrishnapanicker, S. Varghese, J.T. Guthrie. Carbohydr. Polym. 80, 3 (2010)

[9] Pelissari, F., P.A. Sobral, F. Menegalli. Cellulose 21, 1 (2014)

[10] Enock, T.K., C.K. King'ondu, A. Pogrebni, Y.A.C. Jande. International Journal of Electrochemistry. 1, 1 (2017)

[11] Yuliusman, W.W. Purwanto, Y.S. Nugroho. International Journal of Technology 3, 492-503 (2015)

[12] Yuliusman, M.K. Afdhol, A. Sanal. IOP Conf. Ser.: Mater. Sci. Eng. 316, 1 (2018)

[13] Yuliusman, Nasruddin, A. Sanal, A. Bernama, F. Haris, I.T. Ramadhan. IOP Conf. Ser.: Mater. Sci. Eng. 176, 1 (2017)

[14] Nasruddin, A. Wijanarko, G. Ramadhan, M.A. Budiyanto, O. Sahat. PGSRET Conf. IEEE Xplore. 17, 9-15 (2017)

[15] Guo, J. W.S. Xu, Y.L. Chen, A.C. Lua. J. Colloid Interface Sci. 281, 285-290 (2005)

[16] Jawad, A.H., R.A. Rashid, M.A.M. Ishak, L.D. Wilson. Desalination and Water Treatment 57, 25194-25206 (2016)

[17] Yuliusman, Nasruddin, M.K. Afdhol, F. Haris, R.A. Amiliana, A. Hanafi, I.T. Ramadhan. Advance Science Letter 23, 6 (2017)

[18] Mianowski, A., M. Owczarek, A. Marecka. Energy Sources Part A 29, 1 (2007)

[19] Lempang, M. Info Teknis EBONI 11, 2 (2014)

[20] Sumardiyono, D.W., Herawati, Supriyono. Biomedika 10, 2 (2017)

[21] Villegas, P.J. Int. J. of Sustainable Energy and Environmental Research 5, 2 (2016) 